\title{
Application of TGMD-2 for Children with Intellectual Disability
}

\author{
Juriana Juriana $^{1}$, Yuliasih Yuliasih ${ }^{2}$, Adinda Bunga Berliana ${ }^{3}$ \\ \{juriana@unj.ac.id ${ }^{1}$,yuliasih@uinjkt.ac.id ${ }^{2}$, adindabungaberliana@gmail.com ${ }^{3}$ \}
}

Sport Science Faculty of Universitas Negeri Jakarta ${ }^{1,2}$ Indonesian Sport National Committee of Jakarta ${ }^{3}$

\begin{abstract}
This study aims to apply TGMD-2 as measurement of fundamental motor skill for intellectual disablity children. The research was conducted by survey method by describing the status of fundamental motor skill with data collection technique using test and measurement with Test of Gross Motor Development-2. The study was conducted at the Velodrome Athletic Stadium in January until May 2018. The sample used in this study amounted to 84 intelectual disability children registred as Special Olympic Indonesia (SOIna) athletes with moderate of motor ability. The results of the tests and measurements obtained were the total fundamental motor skill shows that $8.3 \%$ of the children were in the category of low, $57.1 \%$ of the children were in the category of moderate, and $34.5 \%$ of the children were in the category of high. Thus, it can be stated that children registrated as SOIna athletes still need further training so that their fundamental motor become skilled.
\end{abstract}

Keywords: TGMD-2, Intellectual Disability

\section{Introduction}

Lack of physical activity in children makes a reduced stimulus for children. Children who are in the playing phase should also be channeled to things that spend more energy, the added value is that children can interact with their peers, and can increase their physical activity. Moreover, at the age of 6 years to 12 years are times when children develop fundamental motor skills that they have. Motor development at these times must be stimulated by physical activities that can improve both gross and fine motor skills [1][2][3][4].

Not only in normal children, the development of basic movement skills in children with special needs also needs to be considered every phase. One of the children with special needs is mentally retarded children or intellectual disability or in Indonesia called tuna grahita. Tunagrahita comes from Sanskrit languange, tuna means loss, while grahita is the mind. So, mentally retarded children are children who experience problems in thinking. Mental Retarded is divided into several classifications depending on the level of IQ or intelligence possessed, namely, mild mental retardation, moderate, severe, and very severe [5][6][7].

Physical conditions of mentally retarded children also occur in motor delays, motor delays occur in a person with mental retardation such as standing, walking, etc., 
which makes a negative impact on their motor and physical strength. Therefore mentally retarded children experience delays and disruptions [8][9][10].

There are children with intellectual disability registered as Special Olympics Indonesia or SOIna which the only organization that has been accredited by Special Olympics International (SOI) to organize training and sports competitions for people with intellectual disabilities in Indonesia. SOIna DKI Jakarta athletes who get many achievements are mentally retarded athletes who are included in the high ability group, therefore nurseries and training are needed for athletes with moderate ability so that later the next generation will be formed. However, before starting to be trained, it is necessary to know in advance how fundamental motor skills they have [11][12][13].

Mentally retarded children, by definition, are impaired in their cognitive-verbal abilities; furthermore, recent research has indicated that the mentally retarded have short-term memory deficits and considerable have difficulty in identifying and then attending to the salient features within a stimulus display [14][15].

Fundamental motor skills which become the initial capital to develop the potential of mentally retarded children become accomplished athletes. So it is necessary to do a test to measure the level of development of the fundamental motors [16][17]. Therefore, the authors are interested in knowing the level of basic motion skills in SOIna DKI Jakarta athletes through the research that conducted in Jakarta which is application of TGMD-2 for children with intellectual disability.

\section{Methods}

This research used a survey method using checklist observation. This research was conducted at Velodrome Athletic Stadium. The time of the study was conducted from January until May 2018. The research samples are 84 intelectual disability children registred as Special Olympic Indonesia (SOIna) athletes with moderate of motor ability. Data analysis used descriptive statistical.

Instruments used in this study is Test of Gross Motor Development 2 (TGMD-2) consist of 6 main dimensions of locomotor skills and 6 main dimension of manipulative skills according to Gallahue and Ozmun [18]. The locomotor skills namely: running, galloping, hopping, leaping, horizontal jump, and sliding. The manipulative skills namely: stationary dribble, striking a stationary ball, catching, kicking, overhead throw, and underhand throw. TGMD-2 was designed for children ages 3 to 10 years, this instrument has been a valid and reliable measurement of motor fundamental skills in adolescents with MR from ag e 11 to 18 years [19]. The tools needed are as follows: cones, duct tape, cube/beam, rope, $10 \mathrm{~cm}$ diameter plastic ball, $25 \mathrm{~cm}$ diameter plastic ball, plastic bat, basket ball, tennis ball, softball ball. The giving values for each subtest as follows: score 1 if the child can show for each criterion, score 0 if the child cannot show for each criterion, the child is given two times the opportunity to do each subtest [20][21][22].

The procedures for each subtes are as follows: 1) Measurement of running skills Instructions: Place cone 1 at a distance of $12 \mathrm{~m}$ and cone 2 at a distance of $15 \mathrm{~m}$ from start. Ask the child to run at full speed \& really stop at cone 2 . Criterias that the child have to show: • Elbows are bent, legs and arms move opposite $\bullet$ Feet flew \& goes quickly / briefly $\bullet$ Landing using the tips or footballs $\bullet$ The angle of the foot approaches the buttocks around 90 degrees 
2) Measurement of galloping skills Instructions: Place cone 1 at a distance of $12 \mathrm{~m}$ and cone 2 at a distance of $15 \mathrm{~m}$ from start. Ask the child to run at full speed $\&$ really stop at cone 2 . Criterias that the child have to show: - The bent arm is pulled toward the waist when floating • Going forward with the first foot / front foot immediately followed by the second foot step and so on $•$ Both legs experience a short floating phase - Can maintain a rhythmic pattern for 4 times in a row

3) Measurement of hopping skills Instructions: Mark duct tape 1 and 2 for 4.5 meters. Ask the child to jump or stick 3 times using the dominant leg and 3 times using the other leg. Criterias that the child have to show: - Legs that are not used are swung forward to produce strength • Still legs remain behind the body - Arms are bent and swung to produce strength. $\bullet$ Take off and land on the dominant leg 3 times in a row. - Take off and land on the other leg 3 times in a row.

4) Measurement of leaping skills Instructions: Mark duct tape 1 and 2 as start and finish as far as $6 \mathrm{~m}$. place the cube right in the middle. Ask the child to stand at the start line, run, jump, and run again until the finish line. Criterias that the child have to show: - When jumping, take off using one leg and land with the other foot. $\bullet$ There are times when the feet float on the ground. - Landing with your arms and legs

5) Measurement of horizontal jump skills Instructions: Mark the start line on the floor with duct tape. The child stands behind the line, asking the child to jump as far as he can. Criterias that the child have to show: - Preparatory movements, knees bent and hands behind the body • Pulling arms forward and up until maximal extension occurs above the head $\bullet$ Take off and land on both feet simultaneously $\bullet$ Lowering arms when landing

6) Measurement of sliding skills Instructions: Place the cone at both ends of the rope which is stretched along $7.5 \mathrm{~m}$. Ask the child to slide from one cone to another, then back to the first cone. Criterias that the child have to show: - The body moves sideways and shoulders are parallel to the straps on the floor $\bullet$ Step aside the first leg movement followed by the next leg • At least 4 steps to the right side continuously - At least 4 steps to the left side continuously

7) Measurement of striking a stationary ball skills Instructions: Place the 10 diameter plastic ball in front of the child at waist level. Ask the child to hit the ball as hard as possible using a bat. Criterias that the child have to show: - The dominant hand over the other hand - Parts of the body that are not used to face the ball with both feet parallel $\bullet$ Waist and shoulders $\bullet$ There is a movement of the pedestal / body load from one foot to the other $\bullet$ When releasing, the bat is just about the ball

8) Measurement of stationary dribbling skills Instructions: Ask the child to dribble basket ball 4 times without moving his feet using one hand and end with catching the ball. Criterias that the child have to show: - Dribble the ball with one hand about waist high $\bullet$ Push the ball with your fingers, not hit $\bullet$ The ball bounces in front or next to the foot $\bullet$ Can maintain $4 x$ reflection without moving feet.

9) Measurement of catching skills Instructions: Mark the distance of $4.5 \mathrm{~m}$ between the child and the thrower and tape. Ask the child to stand on one side \& the pitcher to swing the 10 diameter plastic ball on the other side. Ask the child to catch the ball with his hands between 
his shoulders and waist. Criterias that the child have to show: - The preparatory stage where the hands are in front of the body and the elbows are bent - When the ball arrives, hands extend to reach the ball - The ball is caught only by hand

10) Measurement of kicking skills Instructions: Mark with duct tape $19 \mathrm{~m}$ away from the wall / implement for the child standing and duct tape 2 is $6 \mathrm{~m}$ from the wall to place the ball. Then ask the child to stand up, run and kick the 25 diameter plastic ball as hard as possible. Criterias that the child have to show: - Run endlessly toward the ball $\bullet$ Extend a step or make a little jump just before kicking the ball $\bullet$ The foot that is not used for kicking is behind the ball $\bullet$ Kick the ball using the instep or tip of the foot

11) Measurement of overhead throwing skills Instructions: Place the tape on the floor $7.5 \mathrm{~m}$ away from the wall / implementer. Ask the child to stand behind the tape facing the wall, then ask the child to throw the tennis ball toward the wall / executor. Criterias that the child have to show: - Turning your pelvis and shoulders in a direction that is not a toss - Body weight is transferred to the opposite foot with the hand used for throwing - Body position shows the diagonal / sideways direction to the side that is not to throw the ball $\bullet$ Completion is marked by downward movement of the hand / arm

12) Measurement of underhang throwing skills Instructions: Make a goal for both cones $1 \mathrm{~m}$ away from the wall / executor. Put duct tape as far as 9

meters from the wall, Ask the child to throw the softball ball from below with a strong, so the ball rolled between two cones. Criterias that the child have to show: - Hands swung down \& back, while the chest is facing the cone - The foot opposite the hand being used, stepping forward - The knee is bent toward the bottom of the body $\bullet$ Balls released on the floor must not bounce more than $10 \mathrm{~cm}$

\section{Results}

Based on observation of running skills, there were 11 children (13\%) were included in the Low category, 23 children (27\%) were included in the Moderate category, 50 children (60\%) were in the High category. So, it was concluded that the running skills of SOIna athletes were relatively good.

Figure 1. Diagram of Running Skills

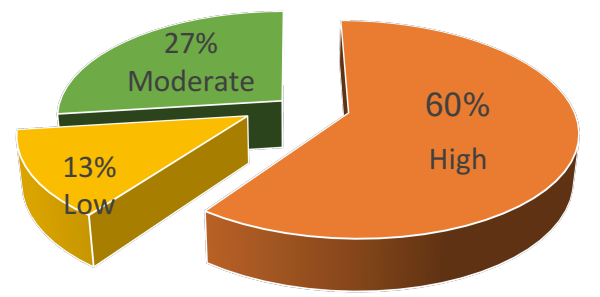

Based on observation of galloping skills, there were 8 children $(9 \%)$ were in the category of Low, 41 children (49\%) were in the Moderate category, 35 children (42\%) were included in 
the category High. Thus, it was concluded that the skill of galloping the SOIna athlete was relatively Moderate.

Figure 2. Diagram of Galloping Skills

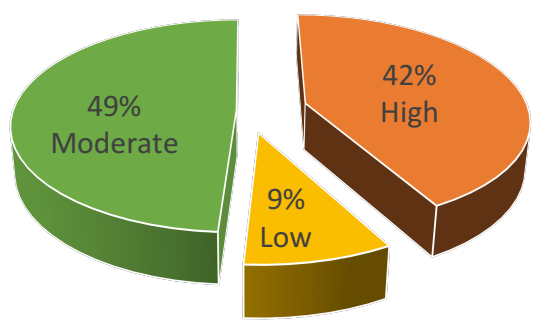

Based on observation of hopping skills, there are 10 children $(12 \%)$ were in the Low category, 39 children (46\%) were in the Moderate category, 35 children (42\%) were included in the category High. Thus, it was concluded that SOIna athlete's skill in hopping was relatively moderate.

Figure 3. Diagram of Hopping Skills

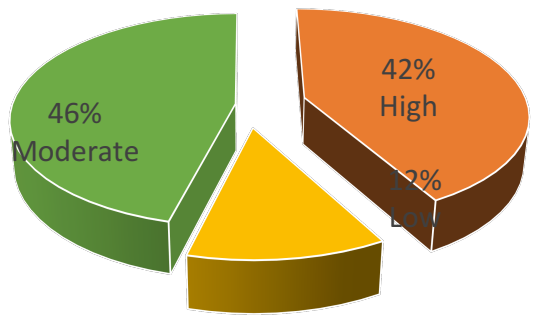

Based on observation of leaping skills, there were 10 children $(12 \%)$ were in the Low category, 22 children (26\%) were in the Moderate category, 52 children (62\%) were in the category High category. Thus, it was concluded that the Leaping skill of SOIna athletes was relatively good.

Figure 4. Diagram of Leaping Skills

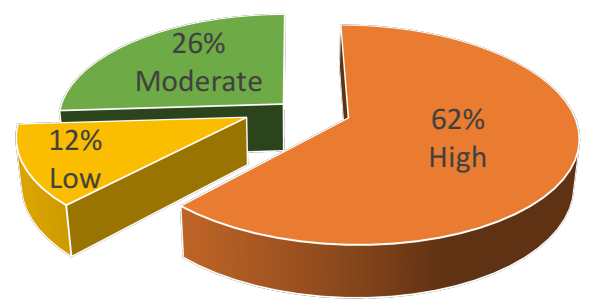


Based on observation of horizontal jump skills, there were 7 children $(8 \%)$ were in the Low category, 45 children (54\%) were in the Moderate category, 32 children $(38 \%)$ were in High category. Thus, it was concluded that SOIna athletes' horizontal jumping skills were relatively Moderate.

Figure 5. Diagram of Horizontal Jump Skills

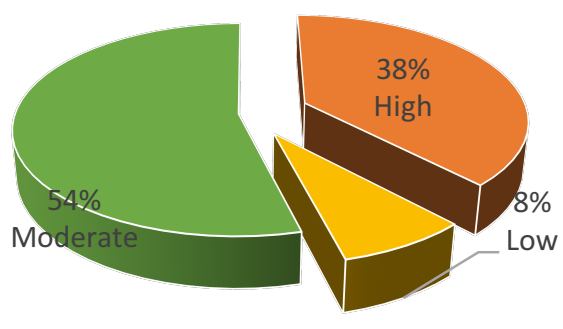

Based on observation of sliding skills, there were 6 children $(7 \%)$ were in the category of Low, 22 children (26\%) were included in the Moderate category, 56 children $(67 \%)$ were included in the High category. So, it was concluded that SOIna athletes' slide skills were relatively good.

Figure 6. Diagram of Sliding Skills

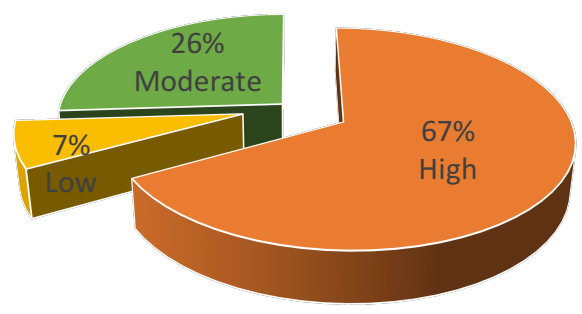

Based on observation of striking a stationary ball, there were 5 children $(6 \%)$ were in the category of Low, 44 children (52\%) were in the Moderate category, 35 children (42\%) were in the High category. It can be concluded that the skill of striking a stationary ball of the SOIna athlete is relatively moderate. 
Figure 7. Diagram of Striking a Stationary Ball

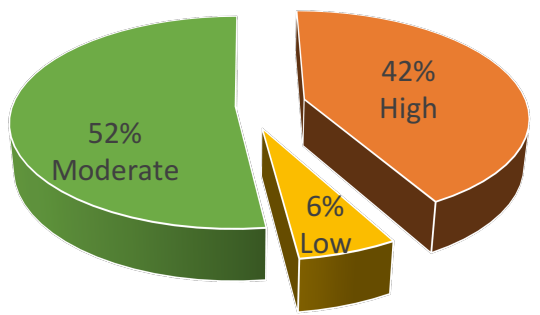

Based on observation of stationary dribbling skills, there were 13 children $(15 \%)$ were in the Low High, 36 children (43\%) were in the Moderate category, 35 children $(42 \%)$ were in the High category. So, it was concluded that the skill of stationary dribbling of the SOIna athlete was relatively Moderate.

Figure 8. Diagram of Stationary Dribbling Skills

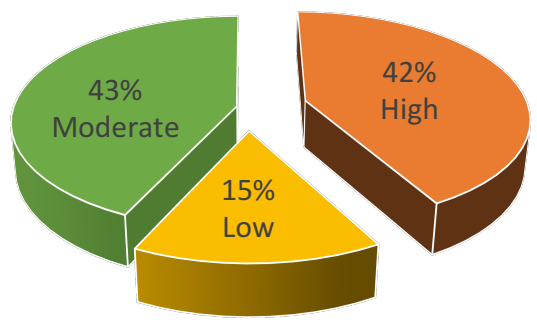

Based on observation of catching skill, there were 5 children $(6 \%)$ were in the category of Low, 5 children $(6 \%)$ were in the Moderate category, 74 children $(88 \%)$ were in the High category. So, it was concluded that the skill of catching of SOIna athletes was relatively good.

Figure 9. Diagram of Catching Skills

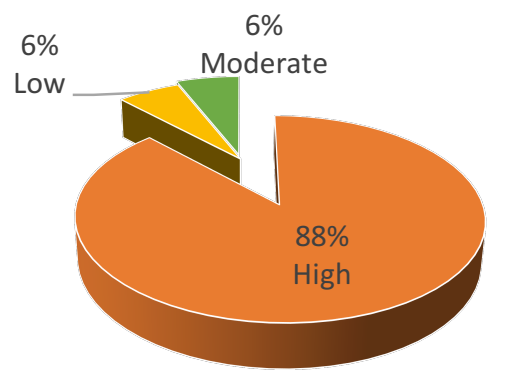

Based on observation of kicking skills, there were 9 children (11\%) in the category of Low, 20 children $(24 \%)$ were in the Moderate category, 55 children $(65 \%)$ were in the category High. So, it was concluded that the skills of kicking SOIna athletes were relatively good. 
Figure 10. Diagram of Kicking Skills

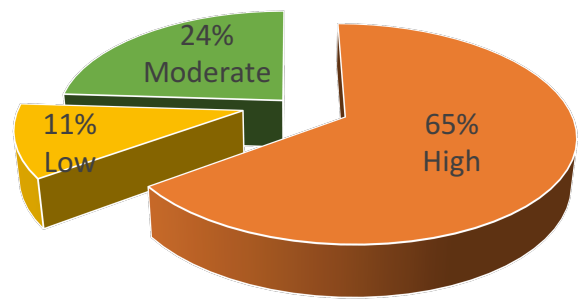

Based on observation of overhead throw skills, there were 8 children $(9 \%)$ were in the category of Low, 36 children (43\%) were in the Moderate category, 40 children (48\%) were in the High category . So, it was concluded that the Overhead Throw skill of SOIna athletes was relatively good

Figure 11. Diagram of Overhead Throw Skills

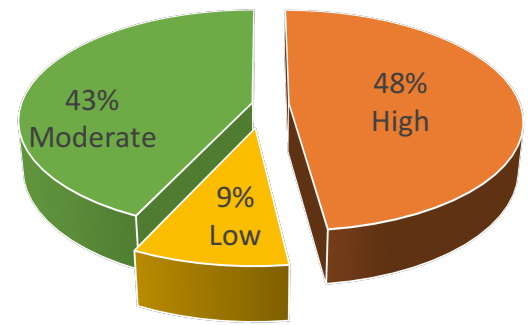

Based on observation of underhand throw, there were 6 children (7\%) were in the category of Low, 38 children (45\%) were in the Moderate category, 40 children (48\%) were in the High category . Thus, it was concluded that the underhand throw skill of SOIna athletes was relatively good.

Figure 12. Diagram of Underhand Throw Skills

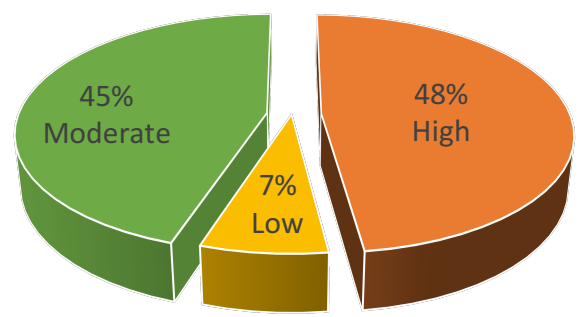




\section{Conclusion}

Based on data analysis and test result carried out in this research, it can be concluded that: Test Results of Fundamental Motor Skill of SOIna DKI Jakarta athlete were categorized as Moderate (57\%), High (35\%) and Low (8\%).

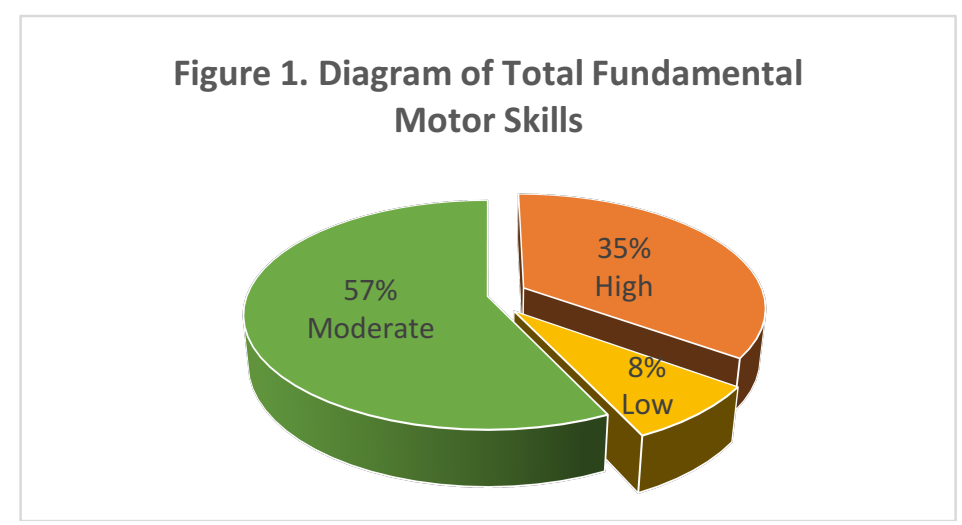

Based on that conclussion, there are some suggestion: 1. Trainer of SOIna should pay more attention to the condition of athlete's fundamental motor skills regularly so that the results of the training are carried out every week; 2. Trainer of SOIna should do a series of tests as training material so that the result of their fundamental motor skills gets better; 3 . Trainer when choose and determine method practice should adjust with physical ability of each athlete, so results from the exercise could achieved optimally; 4. Parents should add physical exercises outside regular schedule exercise for children to increase the fundamental motor skill.

\section{Referencess}

[1] Annemieke, M.R, Ralf F.A., Cox.F, Nienke Boonstra, Maria W.G., Nijhuis-van der Sanden. Measurement of Fine-Motor Skill in Young Children with Visual Impairment. Journal of Developmental and Physical Disabilities. (2015).

[2] Septiyani, P. Pengaruh Aktifitas Akuatik Terhadap Kemampuan Motorik Anak Tunagrahita Ringan, EJournal. (2015).

[3] Sugianto. Belajar Gerak. Jakarta : Pusdiklat KONI PUSAT. (1993).

[4] Utari, Y.I. Upaya Meningkatkan Gerak Dasar Lokomotor Anak Tunagrahita Ringan Melalui Permainan Tradisional. Jurnal Pendidikan Olahraga dan Kesehatan. (2015).

[5] Juriana. MELEK ABK yuk?. Jakarta: CV. Alumgadan Mandiri. (2016).

[6] Santrock, J.W. Child Development. New York: McGraw Hill. (2007).

[7] Wall, A.E. Physically awkward children: A motor development perspective. New York: Plenum Press. (1982).

[8] Hakim, A.R. Pengaruh Usia dan Latihan Keseimbangan Terhadap Kemampuan Motorik Kasar Anak Tunagrahita Kelas Bawah Mampu Didik Sekolah Luar Biasa. Journal of Physical Education and Sports, Vol.2(1). (2013).

[9] Wiradihardja, S. Perkembangan Motorik, Jakarta: CV Alumgadan Mandiri. (2016). 
[10] Widianto, F.T. Keterampilan Gerak Dasar Anak Tunagrahita Ringan. Journal of Physical Education, Sport, Health and Recreation, Vol.1(1). (2012).

[11] Samsudin. Pembelajaran Motorik di Taman KanakKanak. Jakarta: Litera. (2008).

[12] Septiyani, P. Pengaruh Aktifitas Akuatik Terhadap Kemampuan Motorik Anak Tunagrahita Ringan, EJournal. (2015).

[13] Utari, Y.I. Upaya Meningkatkan Gerak Dasar Lokomotor Anak Tunagrahita Ringan Melalui Permainan Tradisional. Jurnal Pendidikan Olahraga dan Kesehatan. (2015).

[14] Juriana. MELEK ABK yuk?. Jakarta: CV. Alumgadan Mandiri. (2016).

[15] Wall, A.E. Physically awkward children: A motor development perspective. New York: Plenum Press. (1982)

[16] Gregory, P.V., Isaacs, L.D. Human Motor Development: A lifespan approach. New York: McGraw-Hill Companies. (2012).

[17] Thanda Aye, Khin Saw Oo, Myo Thuzar Khin, Tsumi Kuramto-Ahuja, Hitoshi Maruyama. Reliability of the test of gross motor development second edition (TGMD-2) for Kindergarten Children in Myanmar. Journal of Physical Therapy Science. (2017).

[18] Gallahue, D.L., Ozmun, J.C., Goodway., J.D. UnderstandingMotor Development. New York: McGraw-Hill Companies, 2012. (2012).

[19] Foley , J.T., Stephen Harvey , Hae-Ja Chun \& So-Yeun Kim. The Relationships Among Fundamental Motor Skills, Health-Related Physical Fitness, and Body Fatness in South Korean Adolescents With Mental Retardation, Research Quarterly for Exercise and Sport, 79:2, 149-157. (2008).

[20] Gallahue, D.L., Ozmun, J.C., Goodway., J.D. UnderstandingMotor Development. New York: McGraw-Hill Companies, 2012. (2012).

[21] Suzanne, H et.al. Reliability and Validity of the TGMD-2 in Primary-School-Age Children With Visual Impairments. Journal of IFAPA, Vol.27. (2010).

[22] Kim, Youngdeok et,al. Examining Rater Effects of the TGMD-2 on Children With Intellectual Disability. Journal of IFAPA, Vol.29. (2012). 